\title{
Genomic imprinting in plants-revisiting existing models
}

\author{
Rita A. Batista and Claudia Köhler \\ Department of Plant Biology, Uppsala BioCenter, Swedish University of Agricultural Sciences and Linnean Centre \\ for Plant Biology, Uppsala SE-750 07, Sweden
}

\begin{abstract}
Genomic imprinting is an epigenetic phenomenon leading to parentally biased gene expression. Throughout the years, extensive efforts have been made to characterize the epigenetic marks underlying imprinting in animals and plants. As a result, DNA methylation asymmetries between parental genomes emerged as the primary factor controlling the imprinting status of many genes. Nevertheless, the data accumulated so far suggest that this process cannot solely explain the imprinting of all genes. In this review, we revisit the current models explaining imprinting regulation in plants, and discuss novel regulatory mechanisms that could function independently of parental DNA methylation asymmetries in the establishment of imprinting.
\end{abstract}

Supplemental material is available for this article.

Genomic imprinting is an epigenetic phenomenon rendering alleles to be differentially expressed depending on their parental origin. Thus, a given gene could be preferentially expressed from the maternal allele (maternally expressed gene [MEG]), or from the paternal allele (paternally expressed gene [PEG]). Imprinting is not widespread in eukaryotes: It is restricted to flowering plants, therian mammals, and some insects. This suggests that this epigenetic phenomenon is the result of convergent evolution, having evolved at least three independent times in the eukaryote tree of life (Barlow and Bartolomei 2014; Pires and Grossniklaus 2014). While in insects genomic imprinting is able to trigger parental-specific repression of whole chromosomes, in mammals and flowering plants it impacts mostly single genes, or gene clusters (Field et al. 2004; Wolff et al. 2011; Zhang et al. 2011, 2016; Barlow and Bartolomei 2014). Imprinted gene expression occurs in embryonic, placental, and adult tissues of mammals. In contrast, in flowering plants, imprinting is mainly restricted to the endosperm, with few instances of imprinted genes being described in the embryo (Jahnke and Scholten 2009; Gehring et al. 2011; Hsieh et al. 2011;

[Keywords: DNA methylation; genomic imprinting; Polycomb group proteins; plants]

Corresponding author: claudia.kohler@slu.se

Article is online at http://www.genesdev.org/cgi/doi/10.1101/gad.332924. 119.
Nodine and Bartel 2012; Raissig et al. 2013; Waters et al. 2013; Del Toro-De León et al. 2014; Pignatta et al. 2014). Because such examples of genomic imprinting in the embryo are rare, this review will exclusively focus on imprinting processes occurring in the endosperm.

Much like the mammalian placenta, the endosperm is an ephemeral tissue that does not contribute to the next generation. Nevertheless, it is essential for the nourishment and growth of the embryo as well as for seed viability. The endosperm and the embryo are both derived from a double-fertilization event, which involves two identical haploid sperm cells and two distinct female gametes: the haploid egg cell, which will give rise to the embryo, and the homodiploid central cell, which will give rise to the endosperm (Drews and Koltunow 2011; Baroux and Grossniklaus 2019). Consequently, the endosperm is a triploid tissue, composed of two maternal copies and one paternal genome copy.

Several theories aim to explain the evolution of genomic imprinting (for reviews, see Patten et al. 2014; Rodrigues and Zilberman 2015). One of the most prominent is the kinship or parental conflict theory developed by Haig and Westoby (1989). This theory posits that maternal and paternal interests are distinct in organisms where the female can bear offspring derived from multiple males. In these instances, it will be in the best interest of the female to equally allocate resources to her offspring, amplifying the probability of maternal reproductive success. On the other hand, the paternal interest is to maximize the survival of its own offspring. Thus, reproductive advantage will be given to those fathers whose progeny is able to outgrow its half-siblings. This would then be translated in the selection of parentally biased gene expression (i.e., genomic imprinting), with MEGs and PEGs being theoretically predicted to have distinct functions and developmental effects, reflecting the distinct interests of each parent (Haig and Westoby 1989; Costa et al. 2012; Jiang and Kohler 2012). In agreement with this, increasing the genomic dosage of one of the parents in the endosperm by disturbing

(C) 2020 Batista and Köhler This article is distributed exclusively by Cold Spring Harbor Laboratory Press for the first six months after the full-issue publication date (see http://genesdev.cshlp.org/site/misc/terms.xhtml). After six months, it is available under a Creative Commons License (Attribution-NonCommercial 4.0 International), as described at http://creativecommons.org/licenses/by-nc/4.0/. 
the two maternal:one paternal genomic ratio leads to parent-of-origin-specific seed phenotypes: While maternal genome excess reduces endosperm growth, leading to smaller and sometimes inviable seeds, paternal genome excess has the opposite effect, and frequently causes seed inviability (Brink and Cooper 1947; Lin 1984; Scott et al. 1998; Stoute et al. 2012; Sekine et al. 2013; Rebernig et al. 2015; Roth et al. 2019). These phenotypes are associated with misregulated expression of imprinted genes (Erilova et al. 2009; Tiwari et al. 2010; Schatlowski et al. 2014; Florez-Rueda et al. 2016), and seed inviability of paternal excess crosses can be prevented by rescuing PEG expression (Kradolfer et al. 2013; Wolff et al. 2015; Erdmann et al. 2017; Huang et al. 2017; Jiang et al. 2017; Martinez et al. 2018; Wang et al. 2018), showing that the function of imprinted genes has a substantial impact on endosperm development. These data are in line with the proposed function of imprinted genes acting as "gatekeepers" of endosperm development: These genes are sensitive to changes in parental dosages, and their misregulation causes seed failure (Gutierrez-Marcos et al. 2003).

The function of many imprinted genes is still unknown; nevertheless, several imprinted genes have been implicated in key developmental pathways, such as nutrient transfer (Gutiérrez-Marcos et al. 2004; Costa et al. 2012), endosperm proliferation (Figueiredo et al. 2015) and control of seed size (Yuan et al. 2017). Importantly, epigenetic regulators involved in the establishment of genomic imprinting are themselves imprinted, and disruption of their activity leads to dramatic seed abortion phenotypes (Grossniklaus et al. 1998; Kinoshita et al. 1999; Luo et al. 2000). This is associated with loss of imprinting at many loci (Hsieh et al. 2011; Wolff et al. 2011; Hornslien et al. 2019|, indicating that imprinting is crucial for endosperm and seed development.

Underlying the biased parental expression of imprinted genes is a set of epigenetic modifications-the imprintswhich are established during gametogenesis (Barlow 1995). For a given gene to show parentally biased expression, the imprint should be established exclusively in one of the two parental genomes, thus generating an asymmetry between the maternal and paternal alleles (Barlow 1995). This asymmetry largely depends on the fact that the epigenetic pathways acting in maternal and paternal gametes are different (Fig. 1A-D), allowing the same DNA sequence to be distinctly marked. The imprints are then inherited to the fertilization products, where they need to be maintained in order for parentally biased gene expression to be manifested. In mammals, DNA methylation asymmetry between parental alleles has long been recognized as the predominant factor controlling imprinting of many loci (Barlow 1993; Barlow and Bartolomei 2014). In these cases, DNA methylation is considered a primary imprint, which can be defined as an epigenetic mark that is established during gametogenesis, stably inherited in the fertilization products, and sufficient on its own for imprinted expression (Barlow 1994). It can be distinguished from a secondary imprint, since the latter is deposited as a consequence of the primary imprint, and acts in conjunction with it to enforce parental specific expression (Barlow 1994). Numerous studies that characterized the imprintome and epigenome of various plant species also point to DNA methylation being a primary imprint there (Satyaki and Gehring 2017). Notwithstanding, in plants a particular histone modification-trimethylation of lysine 27 of histone $\mathrm{H} 3$ (H3K27me3) - has also been shown to be essential for imprinting (Gehring et al. 2006; Jullien et al. 2006a; Makarevich et al. 2008; Hsieh et al. 2011; Wolff et al. 2011; Moreno-Romero et al. 2016; Hornslien et al. 2019). This histone modification is established by Polycomb group (PcG) proteins, and promotes chromatin condensation and inhibition of transcription (Mozgova and Hennig 2015).

In plants, DNA methylation asymmetries between female and male genomes are caused by an extensive DNA demethylation of the maternal genome, which occurs during central cell development, but not during sperm cell development (Fig. 1B; Choi et al. 2002; Gehring et al. 2009; Park et al. 2016). This asymmetry is in itself sufficient to trigger imprinted maternal-specific expression of some genes (Choi et al. 2002; Kinoshita et al. 2004; Gehring et al. 2006, 2009; Hsieh et al. 2011). Nonetheless, DNA demethylation of some maternal loci can be associated with the deposition of H3K27me3. This mechanism of sequential DNA demethylation and H3K27me3 deposition can also trigger imprinted expression, leading to silencing of the maternal alleles (Moreno-Romero et al. 2016). These data have led to the model in which DNA methylation emerges as the primary imprint controlling parentally biased gene expression, with H3K27me3 being considered a secondary imprint, since deposition of this mark in the maternal genome is thought to require prior DNA demethylation of the target regions (Weinhofer et al. 2010; Moreno-Romero et al. 2016). In this review, we evaluate this model of imprinting based on available data in different species. Moreover, we explore DNA methylation-independent mechanisms that can contribute to imprinted gene expression, as well as discuss their potential impact in shaping the imprintome of several plant species.

\section{The maternal genome is actively demethylated during gametogenesis}

In plants, cytosine bases can be methylated in three different sequence contexts: $\mathrm{CG}, \mathrm{CHG}$, and $\mathrm{CHH}$ (where $\mathrm{H}$ corresponds to A, T, or G) (Law and Jacobsen 2010). This epigenetic mark is usually found in transposable elements (TEs) where it promotes the silencing of these repetitive sequences, preventing their reactivation and transposition (Zhang et al. 2018). DNA methylation can also be found in gene-rich regions, and its presence in gene promoters correlates with transcriptional repression (Niederhuth et al. 2016). The genomic DNA methylation landscape is shaped by the action of different pathways: de novo methylation, maintenance methylation, and demethylation, and each of these has been implicated in the regulation of imprinted gene expression in plants. Among these, the DNA demethylation pathway mediated 
A

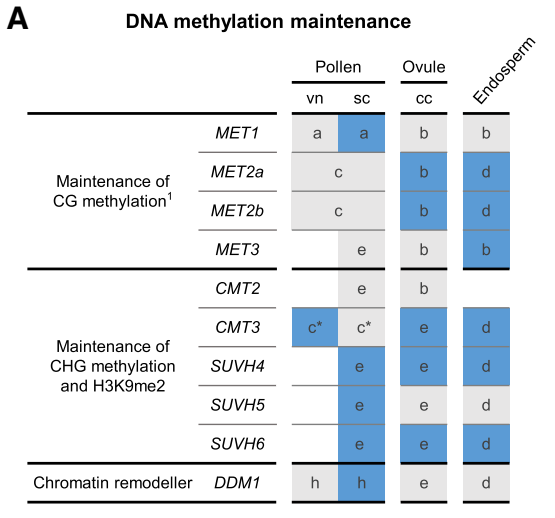

C

C Polycomb Repressive Complexes

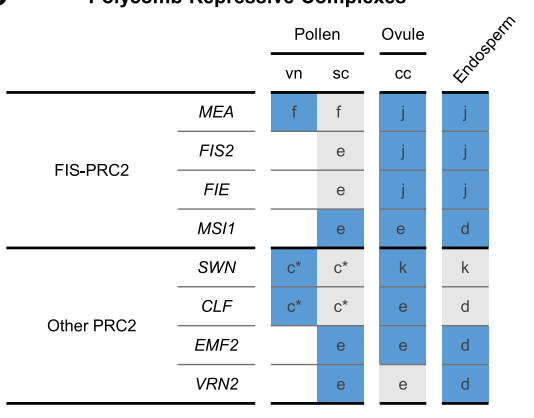

B

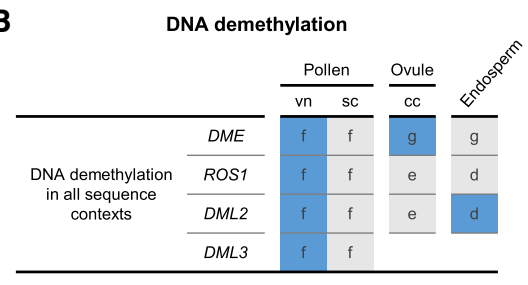

D

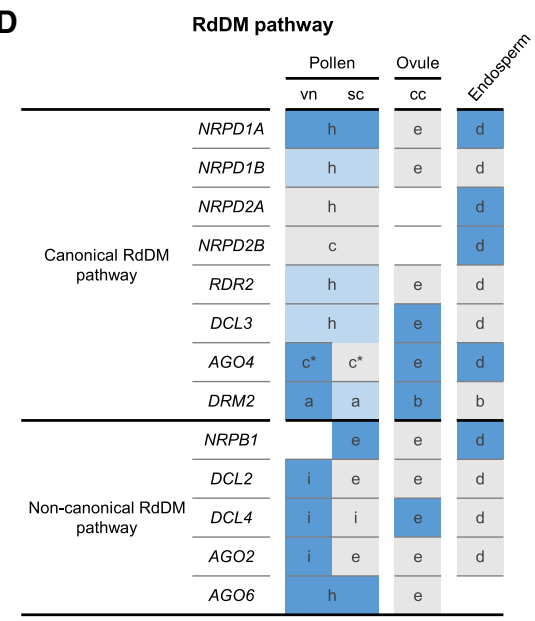

Figure 1. Expression of genes belonging to the main epigenetic pathways in the Arabidopsis female gametophyte, male gametophyte, and endosperm. The epigenetic pathways analyzed here are DNA methylation maintenance $(A)$, DNA demethylation $(B)$, Polycomb repressive complexes $(C)$, and $\operatorname{RdDM}(D)$. Expression is shown for the vegetative nucleus (vn), the sperm cell (sc), the central cell (cc), and the endosperm. Expression data were retrieved from the sources indicated in each respective square. (a) Calarco et al. (2012); (b) Jullien et al. (2012); (c) Borges et al. (2008); (d) Belmonte et al. (2013); (e) Wuest et al. (2010); (f) Schoft et al. (2011); (g) Choi et al. (2002); (h) Slotkin et al. (2009); (i) Martínez et al. (2016); (j) Luo et al. (2000); (k) Wang et al. (2006). (1) Methyltransferase activity of MET2a, MET2b, and MET3 has not yet been assessed. $\left({ }^{*}\right)$ Genes were described as being expressed in pollen and absent in sperm cells (Borges et al. 2008).

by the DNA glycosylase DEMETER (DME) is essential for genomic imprinting. DME, similarly to the remaining Arabidopsis thaliana glycosylases DEMETER LIKE 2-3 (DML2-3) and REPRESSOR OF SILENCING 1 (ROS1), is able to excise methylated cytosine bases in any sequence context, through the base excision repair mechanism (Choi et al. 2002; Gong et al. 2002; Morales-Ruiz et al. 2006; Penterman et al. 2007; Ortega-Galisteo et al. 2008; Gehring et al. 2009). DME is active both in the central cell of the female gametophyte, and in the vegetative cell of pollen, where DML2-3 and ROS1 are also present (Fig. 1B; Choi et al. 2002; Schoft et al. 2011). In these cells, DME demethylates TEs and small repetitive sequences, and targeted regions seem to be partially identical in the central cell and in the vegetative nucleus (Gehring et al. 2009; Hsieh et al. 2009; Calarco et al. 2012; Ibarra et al. 2012; Park et al. 2016). Similarly, in rice, demethylation of the central cell and the vegetative nucleus is observed, likely mediated in both tissues by the ROS1 ortholog ROS1a (Park et al. 2016; Kim et al. 2019).

Demethylation of TEs in the central cell of the female gametophyte and the vegetative cell of pollen has been proposed to be part of a defense mechanism set up to efficiently silence these TEs in the egg and sperm cells (McDonald et al. 2005; Gehring et al. 2009; Hsieh et al. 2009; Calarco et al. 2012; Ibarra et al. 2012). Demethylation of TEs leads to their transcriptional activation and production of small interfering RNAs (siRNAs) (Slotkin et al. 2009). siRNAs generated from transcriptionally active TEs can then initiate DNA methylation through the noncanonical RNA-directed DNA methylation (RdDM) pathway, which uses them as guides to target the DNA methylation machinery to homologous sequences (Cuerda-Gil and Slotkin 2016; Zhang et al. 2018). The siRNAs that are produced in the central cell and vegetative nucleus are hypothesized to travel to the adjacent gametes-the egg and sperm cells-and promote DNA methylation of TE sequences there, enforcing their silencing (Slotkin et al. 2009; Calarco et al. 2012). Consistent with this hypothesis, siRNAs expressed in the vegetative cell and a miRNA expressed in the central cell are able to confer silencing of reporters expressed in sperm and egg cells, respectively (Ibarra et al. 2012; Martínez et al. 2016).

Because imprinted genes often show enrichment of TEs in their flanking regions (Gehring et al. 2009; Wolff et al. 2011; Rodrigues et al. 2013; Pignatta et al. 2014; Hatorangan et al. 2016; Yuan et al. 2017), DME-mediated demethylation of these elements can have an influence on the expression of the nearby imprinted genes. Hence, the primary role of DME and other DNA glycosylases is not to generate imprinted gene expression. Instead, imprinted gene expression arises as a byproduct of DME activity on TEs (McDonald et al. 2005; Gehring et al. 2009; Hsieh et al. 2009). Nevertheless, DME-mediated DNA 
demethylation of the central cell has a direct impact on the epigenetic landscape of the endosperm and is determinant for imprinting, while demethylation of the vegetative nucleus seems to have an indirect impact: In Arabidopsis, siRNAs produced in the vegetative nucleus accumulate in the sperm cells and are associated with MEGs (Calarco et al. 2012). Furthermore, these loci are highly methylated, suggesting that the siRNAs produced in the vegetative nucleus are important to enforce silencing of paternal alleles of MEGs in the sperm cell (Calarco et al. 2012). Besides the role of RdDM in promoting methylation of the paternal alleles of some MEGs, the activity of DNA METHYLTRANSFERASE 1 (MET1) and CHROMOMETHYLASE 3 (CMT3) is required for the maintenance of CG and CHG methylation levels in sperm cells, respectively, ensuring epigenetic inheritance (Fig. 1A; Saze et al. 2003; Jullien et al. 2006b; Calarco et al. 2012).

Together, the different dynamics of DNA methylation pathways in male and female gametes results in the inheritance of a locally demethylated maternal genome and a hypermethylated paternal genome in the endosperm (Table 1; Fig. 1A-D). As a consequence, differentially methylated regions (DMRs) between both parental genomes can be defined, where the maternal allele is often hypomethylated, especially in the context of DMRs associated with imprinted genes (Gehring et al. 2009; Zhang et al. 2011, 2014; Ibarra et al. 2012; Park et al. 2016; Yuan et al. 2017). Interestingly, inheritance of a demethylated maternal genome in the endosperm is observed in all plants analyzed thus far (i.e., A. thaliana, A. lyrata, castor bean, rice, and maize), suggesting that the process of central cell demethylation is conserved across different species (Gehring et al. 2009; Hsieh et al. 2009; Zemach et al. 2010; Zhang et al. 2011, 2014; Ibarra et al. 2012; Rodrigues et al. 2013; Xu et al. 2014; Klosinska et al. 2016; Park et al. 2016; Yuan et al. 2017).

\section{Maternal DNA demethylation as a primary driver of imprinted expression}

Maternally expressed genes dependent on parental DNA methylation asymmetries

Multiple studies have previously demonstrated that MEGs are often associated with DMRs where the paternal allele has higher methylation than the maternal allele: Around $28 \%-54 \%$ of MEGs are associated with at least one DMR across different species (Table 1). Because of its ability to repress transcription (Niederhuth et al. 2016), the presence of DNA methylation on the paternal alleles of these genes leads to their silencing, while absence of this mark on the maternal alleles allows for their transcription. This simple mechanism of imprinting is associated with the regulation of several MEGs (Fig. 2A; Jullien et al. 2006b; Tiwari et al. 2008; Vu et al. 2013). One of these genes is FLOWERING WAGENINGEN (FWA); FWA contains a SINE TE in its vicinity, and this repetitive element is methylated in sporophytic tissues through the activity of RdDM and MET1, repressing the transcription of FWA in these tissues (Kinoshita et al. 2004, 2006). In sperm, the activity of MET1 allows for the maintenance of DNA methylation in this TE, while in the central cell the SINE element is targeted for DNA demethylation by $\mathrm{DME}$, a process required for the expression of the maternal allele of FWA in the endosperm (Kinoshita et al. 2004, 2006). Introducing met1 paternally prevents the methylation of the SINE element in sperm, leading to activation of the paternal allele and to biallelic expression of FWA in the endosperm (Kinoshita et al. 2004). On the other hand, introducing dme1 maternally prevents demethylation of the SINE TE, and consequently, the maternal allele of FWA is not expressed in the endosperm (Kinoshita et al. 2004). This illustrates the requirement of DME for maternal activation of MEGs, as well as the requirement of MET1 for paternal repression of these genes (Fig. 2A). Imprintome studies of met 1 and dme corroborate this scenario, showing that a subset of MEGs become biallelically expressed in met1 paternal mutants, and maternally repressed in dme maternal mutants (Hsieh et al. 2011; Hornslien et al. 2019).

In this way, DNA methylation, or more specifically, the parental asymmetry of DNA methylation, has the potential to act as the exclusive mark controlling the imprinting of several MEG loci. In agreement with this model, around $26 \%$ of MEGs in A. thaliana and $31 \%$ of MEGs $A$. lyrata are exclusively marked with hypomethylated DMRs (Table 1), supporting the idea that the imprinting of these genes is controlled by parental DNA methylation asymmetries alone. Nevertheless, it is interesting to note that many MEGs are not associated with any of the epigenetic marks assessed so far (hypomethylated DMRs and paternal accumulation of H3K27me3) (Table 1). This, together with the observation that the imprinting of many MEGs is not influenced by met1 (Hornslien et al. 2019), suggests that there are additional mechanisms controlling the imprinting of MEGs, and that these mechanisms possibly rely on yet to be determined epigenetic modifications.

Paternally expressed genes dependent on parental DNA methylation asymmetries and H3K27me3

Besides controlling the imprinting of several MEGs, parental asymmetries in DNA methylation can also lead to parental-specific deposition of the repressive histone mark H3K27me3 by PcG proteins, a process often required for PEG imprinting. PcG proteins act as multimeric complexes denominated Polycomb repressive complexes (PRCs). These complexes can be distinguished as type 1 (PRC1), or type 2 (PRC2), the latter being responsible for the deposition of H3K27me3 (Mozgova and Hennig 2015). In $A$. thaliana, PRC2 complexes can be comprised of distinct sets of proteins and act at different stages of plant development (Mozgova et al. 2015). Notwithstanding, in this species, genomic imprinting mediated by $\mathrm{H} 3 \mathrm{~K} 27 \mathrm{me} 3$ relies on the FERTILISATION INDEPENDENT (FIS)-PRC2 complex (Gehring et al. 2006; Jullien et al. 2006a; Makarevich et al. 2008; Hsieh et al. 2011; Wolff et al. 2011; Moreno-Romero et al. 2016, 2019), which is composed of 
Table 1. Presence of epigenetic modifications on imprinted genes in different plant species

\begin{tabular}{|c|c|c|c|c|c|c|c|}
\hline \multirow[b]{2}{*}{$\begin{array}{l}\text { Imprinting } \\
\text { status }\end{array}$} & \multirow[b]{2}{*}{ Species } & \multicolumn{6}{|c|}{ Genes with } \\
\hline & & DMR & o H3K27me3 & $\begin{array}{l}\text { o } \mathrm{H} 3 \mathrm{~K} 27 \mathrm{me} 3 \\
\text { and DMR }\end{array}$ & DMR only & o H3K27me3 only & $\begin{array}{l}\text { No DMR or } \\
\text { H3K27me } 3\end{array}$ \\
\hline \multirow[t]{5}{*}{ MEGs } & $\begin{array}{c}\text { Arabidopsis } \\
\text { thaliana }\end{array}$ & $28 \%(23 / 81)^{\mathrm{a}}$ & $6 \%(5 / 85)^{\mathrm{b}}$ & $2 \%(2 / 81)$ & $26 \%(21 / 81)$ & $4 \%(3 / 81)$ & $68 \%(55 / 81)$ \\
\hline & $\begin{array}{c}\text { Arabidopsis } \\
\text { lyrata }\end{array}$ & $47 \%(16 / 34)^{\mathrm{d}}$ & $4 \%(1 / 26)^{\mathrm{d}, \mathrm{b}}$ & $0 \%(0 / 26)$ & $31 \%(8 / 26)$ & $4 \%(1 / 26)$ & $65 \%(17 / 26)$ \\
\hline & Rice $^{\mathrm{e}, \mathrm{f}}$ & $67 \%(108 / 162)^{\mathrm{e}}$ & $17 \%(16 / 93)^{\mathrm{f}, *}$ & ND & ND & ND & ND \\
\hline & Maize $^{\mathrm{g}}$ & $54 \%(21 / 39)^{\mathrm{g}}$ & $0 \%(0 / 37)^{\mathrm{g}}$ & ND & ND & ND & ND \\
\hline & & DMR & 아 H3K27me3 & $\begin{array}{l}\text { } \mathrm{H} 3 \mathrm{~K} 27 \mathrm{me} 3 \\
\text { and DMR }\end{array}$ & DMR only & ㅇ H3K27me3 only & $\begin{array}{c}\text { No DMR or } \\
\text { H3K27me3 }\end{array}$ \\
\hline \multirow[t]{4}{*}{ PEGs } & $\begin{array}{c}\text { Arabidopsis } \\
\text { thaliana }^{\mathrm{h}}\end{array}$ & $43 \%(18 / 42)^{\mathrm{a}}$ & $\begin{array}{l}90 \%(38 / 42)^{\mathrm{b}} \\
+ \text { H3K9me2 and } \\
\text { CHG: } 64 \% \\
(23 / 36)^{\mathrm{c}}\end{array}$ & $\begin{array}{l}36 \%(15 / 42) \\
+ \text { H3K9me2 and } \\
\text { CHG: } 71 \% \\
(10 / 14)\end{array}$ & $7 \%(3 / 42)$ & $\begin{array}{l}55 \%(23 / 42) \\
+ \text { H3K9me2 and } \\
\text { CHG: } 72 \% \\
(13 / 18)\end{array}$ & $0 \%(0 / 42)$ \\
\hline & $\begin{array}{c}\text { Arabidopsis } \\
\text { lyrata }^{\mathrm{d}}\end{array}$ & $33 \%(16 / 49)^{\mathrm{d}}$ & $51 \%(24 / 47)^{\mathrm{d}, \mathrm{b}}$ & $15 \%(7 / 47)$ & $17 \%(8 / 47)$ & $36 \%(17 / 47)$ & $30 \%(14 / 47)$ \\
\hline & $\operatorname{Rice}^{\mathrm{e}, \mathrm{f}}$ & $81 \%(77 / 95)^{\mathrm{e}}$ & $30 \%(34 / 115)^{\mathrm{f},{ }^{*}}$ & ND & ND & ND & ND \\
\hline & Maize ${ }^{g}$ & $60 \%(41 / 68)^{\mathrm{g}}$ & $52 \%(36 / 68)^{\mathrm{g}}$ & ND & ND & $\mathrm{ND}$ & $\mathrm{ND}$ \\
\hline
\end{tabular}

For each imprinted gene, the presence of the following marks in gene bodies and flanking regions was assessed: (1) differentially DNA methylated regions (DMRs) between endosperm maternal and paternal alleles, or DMRs between endosperm and embryo (only hypomethylated DMRs are reported here); (2) the presence of endosperm H3K27me3 on paternal alleles of MEGs, or the presence of endosperm H3K27me3 on maternal alleles of PEGs; and (3) the presence of endosperm H3K9me2 and CHG on maternal alleles. The data sources are indicated by the superscript letters. (a) Pignatta et al. (2014); (b) Moreno-Romero et al. (2016); (c) Moreno-Romero et al. (2019) (d) Klosinska et al. (2016); (e) Yuan et al. (2017); (f) Chen et al. (2018); (g) Zhang et al. (2014); (h) Del Toro-De León and Köhler (2019). (*) H3K27me3 accumulation is reported without parent-of-origin information. (ND) No data. Imprinted genes of each species were considered as those identified in the data sources associated with each species name. For A. thaliana, the subset of imprinted genes identified by Del Toro-De León and Köhler (2019) which overlapped with genes identified in other imprintome studies was used. For imprinted $A$. lyrata genes, the presence/absence of H3K27me3 was assessed in the A. thaliana homologs, using the data set published by Moreno-Romero et al. (2016). Homologous A. thaliana genes were those originally reported in Klosinska et al. (2016).

FERTILISATION INDEPENDENT SEED 2 (FIS2), MEDEA (MEA), FERTILISATION INDEPENDENT ENDOSPERM (FIE), and MULTICOPY SUPPRESSOR OF IRA 1 (MSI1) (Mozgova and Hennig 2015). FIS-PRC2 functions specifically during reproductive stages, namely, during female gametogenesis and endosperm development (Fig. 1C; Mozgova et al. 2015). In contrast, PRC2 proteins are thought to have reduced or no activity in mature pollen, and while some PRC2 components are expressed in early pollen developmental stages or in vegetative nuclei, they are generally not found in sperm cells (Fig. 1C; Luo et al. 2000; Spillane et al. 2000; Schoft et al. 2011). After fertilization, the FIS-PRC2 is present in the endosperm, and the components MEA and FIS2 are imprinted and maternally expressed (Fig. 1C; Kinoshita et al. 1999; Luo et al. 2000).

Deposition of $\mathrm{H} 3 \mathrm{~K} 27 \mathrm{me} 3$ is anticorrelated with the presence of DNA methylation, both in sporophytic tissues (Roudier et al. 2011; Deleris et al. 2012), as well as in the endosperm (Weinhofer et al. 2010). In line with this, in the endosperm, H3K27me3 is often found to be located in regions that are demethylated by DME in the central cell (Moreno-Romero et al. 2016), some of which are in the vicinity of imprinted genes (Gehring et al. 2009; Hsieh et al. 2009; Ibarra et al. 2012). These observations indicate that in a subset of DME target regions, $\mathrm{H} 3 \mathrm{~K} 27 \mathrm{me} 3$ is deposited by the action of FIS-PRC2 in the central cell, leading to the inheritance of maternally H3K27me3marked alleles. In these loci, maternal DNA demethylation acts as the primary factor for imprinting, by allowing the deposition of $\mathrm{H} 3 \mathrm{~K} 27 \mathrm{me} 3$ on maternal alleles, which can therefore be considered a secondary imprint. Maternal-specific H3K27me3 deposition renders these alleles transcriptionally inactive, while the paternal allele is active, thus defining a PEG (Fig. 2C). In A. lyrata, 15\% of PEGs show maternal H3K27me3 accumulation, which is simultaneously associated with the presence of a hypomethylated DMR (Table 1). The same situation is observed in about $36 \%$ of $A$. thaliana PEGs (Table 1 ), showing that the combination of maternal DNA demethylation, followed by $\mathrm{H} 3 \mathrm{~K} 27 \mathrm{me} 3$ deposition explains the imprinting mechanism of a relevant fraction of PEGs.

One example of such pattern of imprinting is that of the MADS-box transcription factor PHERES 1 (PHE1), which is flanked by $3^{\prime}$ repetitive sequences (Makarevich et al. 2008). These sequences are demethylated in the central cell through the activity of DME, allowing the deposition of H3K27me3 on the maternal alleles of this gene, and, consequently, promoting its repression (Hsieh et al. 2009). Interestingly, the $3^{\prime}$ repetitive sequences in 
A

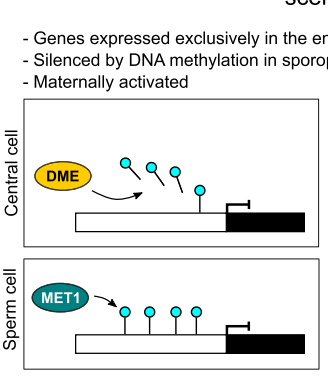

MEGs

scenario 1

B

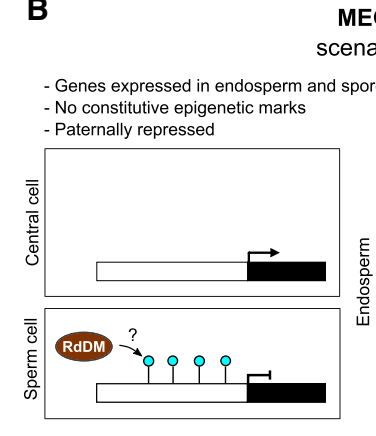

MEGs

cenario 2

- Genes expressed in endosperm and sporophytic tissues - Paternally repressed

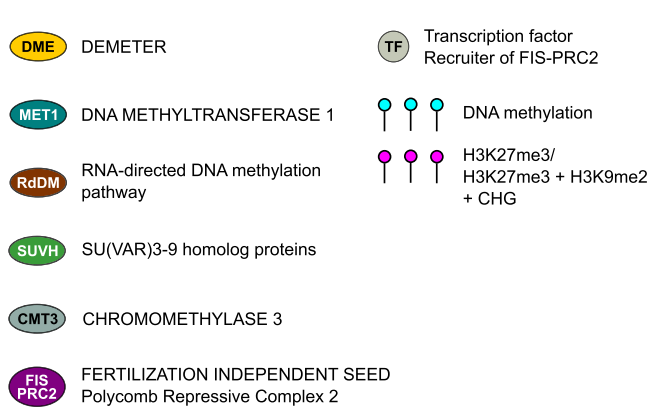

우
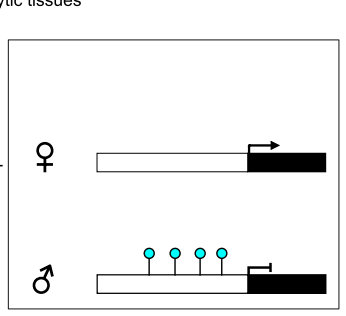

2

C

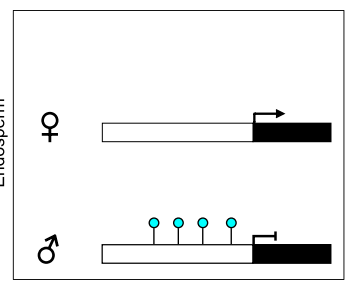

PEGs

scenario 1

- Genes expressed in endosperm and sporophytic tissues - Marked with non-silencing DNA methylation - Maternally repressed
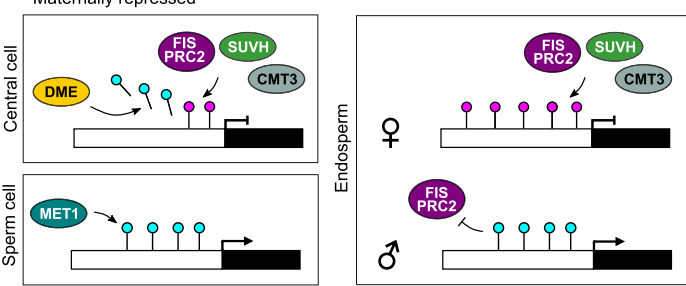

D

PEGs

scenario 2

- Genes expressed in endosperm and sporophytic tissues No constitutive epigenetic marks - Maternally repressed
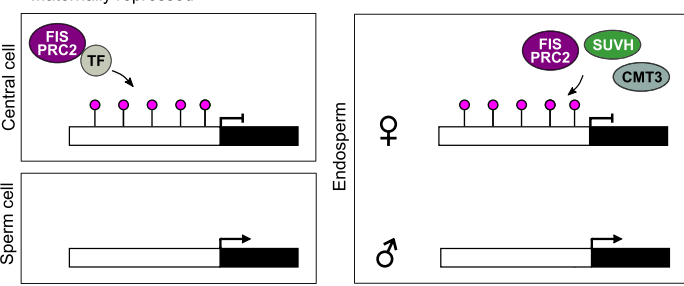

E

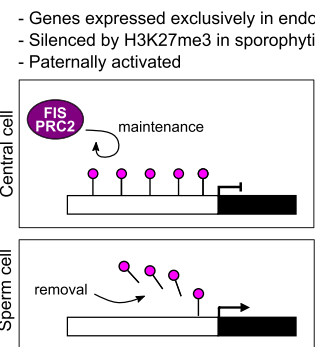

PEGs

scenario 3

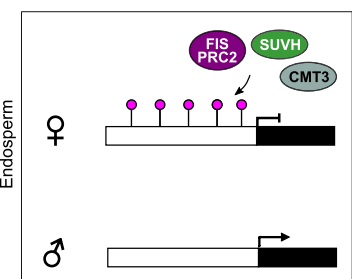

Figure 2. Models of imprinted gene regulation. Different models for the epigenetic regulation of MEGs $(A, B)$ and PEGs $(C-E)$. Models represent the epigenetic status of maternal and paternal alleles in the central cell, sperm cell, and endosperm. The estimated proportion of genes regulated by each of these scenarios is reported in Supplemental Table 1. (A) In this scenario, MEGs are constitutively marked with DNA methylation and are therefore silenced in sporophytic tissues. Maternal expression in the endosperm requires the removal of maternal DNA methylation, as well as maintenance of paternal methylation, which is achieved by DME and MET1, respectively. (B) MEGs that are expressed both in the endosperm and in sporophytic tissues do not carry any constitutive marks. In this scenario, maternal-specific expression is achieved through silencing of the paternal allele, a process that could possibly be mediated by RdDM activity in pollen. $(C)$ These PEGs are constitutively marked with DNA methylation; however, this mark does not lead to transcriptional silencing, but rather prevents the deposition of H3K27me3 by FIS-PRC2. Maternal-specific demethylation mediated by DME allows deposition of $\mathrm{H} 3 \mathrm{~K} 27 \mathrm{me} 3$ in these alleles, leading to their transcriptional inactivation in the endosperm. The presence of DNA methylation in paternal alleles prevents deposition of H3K27me3, allowing for the transcription of this allele. $(D)$ PEGs in this scenario do not show any constitutive epigenetic marks and are expressed in the endosperm as well as in sporophytic tissues. Paternal-specific expression in the endosperm can be achieved through silencing of the maternal alleles in the central cell, mediated by FIS-PRC2 and central cell-specific transcription factors. (E) In this scenario, PEGs show constitutive H3K27me3 and are transcriptionally inactive in sporophytic tissues. This silencing mark is faithfully maintained during female sexual lineage differentiation. On the other hand, decreased activity of the PRC2 in sperm cells causes removal of $\mathrm{H} 3 \mathrm{~K} 27 \mathrm{me} 3$, leading to transcriptional activation of paternal alleles.

the paternal allele of PHE1 are methylated and this is hypothesized to exclude H3K27me3 deposition in the endosperm (Makarevich et al. 2008). This mechanism of paternal exclusion of H3K27me3 via DNA methylation has been proposed to prevent silencing of the paternal alleles of several PEGs (Fig. 2C; Hsieh et al. 2011; Köhler et al. 2012). In line with this, it has been observed that around 33\% (11/33) of the tested PEGs show repression of the paternal allele when met 1 is introduced paternally (Hornslien et al. 2019), similarly to what was reported previously (Hsieh et al. 2011; Wolff et al. 2011). Nevertheless, it remains to be experimentally tested whether this repression is achieved through deposition of H3K27me3.

Besides its role in establishing paternal-specific imprinted gene expression, H3K27me3 was also shown to contribute to the regulation of a small subset of MEGs 
by repressing the paternal alleles of these genes (Gehring et al. 2006; Jullien et al. 2006a; Gerald et al. 2009; Hsieh et al. 2011). In line with this, paternal-specific $\mathrm{H} 3 \mathrm{~K} 27 \mathrm{me} 3$ accumulation is observed in some $A$. thaliana, A. lyrata, and rice MEGs (Table 1). In addition, H3K27me3 has been shown to modulate the expression levels of the active maternal alleles of some MEGs (Hsieh et al. 2011; Hornslien et al. 2019).

\section{H3K27me3: a potential primary driver of imprinted expression}

It is interesting to note that many imprinted genes are not associated with hypomethylated DMRs (Table 1). Moreover, a significant portion of PEGs are exclusively marked with maternal H3K27me3 (36\% in A. lyrata and 55\% in A. thaliana) (Table 1). This suggests that this epigenetic mark is the primary factor controlling the imprinting of a considerable fraction of PEGs, and that deposition of maternal H3K27me3 at many PEGs does not require DME activity, since DNA methylation is not present at these loci (Fig. 2D,E). The observation that in dme the maternal alleles of some PEGs become activated has led to the suggestion that the maintenance of DNA methylation observed in this mutant prevents the deposition of H3K27me3 on maternal alleles, thus avoiding their repression (Hsieh et al. 2011). However, FIS-PRC2 function is likely compromised in $d m e$, since demethylation is required for activation of MEA and FIS2 (Choi et al. 2002; Gehring et al. 2006; Jullien et al. 2006b; Hsieh et al. 2011), which could explain the biallelic expression of some PEGs in this mutant. Furthermore, the observation that H3K27me3 accumulates in DME demethylated regions (Moreno-Romero et al. 2016) does not exclude the possibility that FIS-PRC2 also targets constitutively unmethylated regions. Thus, deposition of $\mathrm{H} 3 \mathrm{~K} 27 \mathrm{me} 3$ in these regions would not require the action of DME in the central cell. In this way, FIS-PRC2 activity could be uncoupled from DME DNA demethylation, opening the possibility for $\mathrm{H} 3 \mathrm{~K} 27 \mathrm{me} 3$ to act as a primary imprint in the female gametes. Furthermore, the fact that the activity of PRC2 proteins is reduced in the male gametophyte and nearly absent from sperm cells (Table 1; Luo et al. 2000; Spillane et al. 2000; Schoft et al. 2011), supports a scenario where $\mathrm{H} 3 \mathrm{~K} 27 \mathrm{me} 3$ can be asymmetrically accumulated in female and male gametes, independently of DNA methylation.

Plant PRC2s do not bind to DNA directly, and have been previously described to be recruited by transcription factors in plants (Xiao et al. 2017; Zhou et al. 2018). Therefore, targeting of PRC2 in the maternal genome could be achieved through the activity of central cell-specific transcription factors. Recent results show that RC/Helitron TEs in the vicinity PEGs carry binding sites for type I MADS-box transcription factors and are associated with maternal H3K27me3 deposition (Batista et al. 2019). Since several type I MADS-box transcription factors are specifically expressed during female gametogenesis (Bemer et al. 2010), it is enticing to hypothesize that these transcrip- tion factors could mediate H3K27me3 deposition by guiding FIS-PRC2 to TEs, having an indirect influence on the imprinting of nearby PEGs. Nevertheless, this hypothesis remains to be experimentally tested.

Once H3K27me3 is deposited in the central cell, this mark can be specifically maintained on maternal alleles during endosperm proliferation: PcG proteins are localized to the DNA replication fork, ensuring propagation of H3K27me3 marked nucleosomes during replication (Hansen et al. 2008; Margueron et al. 2009; Alabert et al. 2014; Jiang and Berger 2017). However, faithful maintenance of H3K27me3 during replication in Drosophila requires also the presence of Polycomb response elements (PREs) (Coleman and Struhl 2017; Laprell et al. 2017). This favors a model where H3K27me3-marked nucleosomes and cis-regulatory elements (PREs) act as a template for the maintenance of this mark on the daughter strands after replication (Hansen et al. 2008; Margueron et al. 2009; Alabert et al. 2014; Coleman and Struhl 2017; Jiang and Berger 2017; Laprell et al. 2017). On the other hand, absence of H3K27me3 on the paternal allele could be maintained in the endosperm due to the ongoing transcription of this allele blocking PRC2 targeting (Blackledge et al. 2015).

Interestingly, H3K27me3 deposition on the maternal alleles of many $A$. thaliana PEGs is frequently associated with CHG methylation and H3K9me2 (Table 1; MorenoRomero et al. 2019). The colocalization of these marks can be detected in the majority of known PEGs and paternally biased genes, and this specific epigenetic signature allows predicting a gene's parental expression bias in the endosperm. Furthermore, the deposition of CHG and H3K9me2 seems to depend on prior H3K27me3 establishment (Moreno-Romero et al. 2019), suggesting that besides being able to act as a primary imprint, H3K27me3 can also enforce silencing by recruiting additional repressive modifications. In A. lyrata, a similar accumulation of CHG methylation has been observed on the maternal alleles of PEGs (Klosinska et al. 2016), suggesting that $\mathrm{H} 3 \mathrm{~K} 27 \mathrm{me} 3$-mediated recruitment of $\mathrm{H} 3 \mathrm{~K} 9 \mathrm{me} 2$ and CHG methylation occurs similarly in this species. Notwithstanding, a thorough profiling of H3K27me3 and $\mathrm{H} 3 \mathrm{~K} 9 \mathrm{me} 2$ in the endosperm of $A$. lyrata is required to validate this hypothesis.

In mammals, despite DNA methylation being the major driver of imprinted gene expression, a subset of genes has been described to be imprinted in a DNA methylation-independent manner (Inoue et al. 2017a,b, 2018). Imprinting is established by the specific deposition of $\mathrm{H} 3 \mathrm{~K} 27 \mathrm{me} 3$ in the oocytes, but not in sperm (Inoue et al. 2017a,b, 2018), resembling the proposed scenario for PEG imprinting in the endosperm. Remarkably, many genes that are imprinted exclusively through DNA methylation remain imprinted in extra-embryonic tissues, while genes marked exclusively by $\mathrm{H} 3 \mathrm{~K} 27 \mathrm{me} 3$ are transiently imprinted: Biased parental expression is observed in preimplantation embryos, with few genes remaining imprinted in later stages of embryo development (Inoue et al. 2017a). This suggests that different imprinting strategies relate to different patterns of expression. 
Together, these observations make a strong case for $\mathrm{H} 3 \mathrm{~K} 27 \mathrm{me} 3$ acting as a primary imprint in the regulation of PEGs in plants and mammals: This imprint can function independently of DNA methylation, it is asymmetrically deposited in female and male gametes, and it can be stably and specifically maintained in the fertilization products. Therefore, it is possible that plants and mammals share this mechanism of imprinting regulation, suggesting that it might have evolved independently through a process of convergent evolution.

\section{A revised model for genomic imprinting}

Taking together the currently available data, we propose to extend the existing models of genomic imprinting, and discuss possible additional pathways regulating MEGs and PEGs, giving special emphasis to DNA methylation-independent mechanisms of imprinting (Fig. 2A-E; Supplemental Table 1). In these models we have accounted for the fact that several imprinted genes are not specifically expressed in the endosperm, but also function elsewhere during plant development (Makarevitch et al. 2013; Waters et al. 2013; Pignatta et al. 2014; Zhang et al. 2014; Klosinska et al. 2016; Moreno-Romero et al. 2019). By analyzing the expression pattern of different imprinted genes in maize, Zhang et al. (2014) proposed an association between the mode of imprinting and the expression of these genes in sporophytic tissues. Different gene expression patterns are associated with different dynamics of epigenetic landscapes throughout development (Roudier et al. 2011). Therefore, it is reasonable to assume that the epigenetic landscape before gametogenesis differs between genes, depending on their expression pattern in sporophytic tissues. This could in turn determine how imprinted expression is established for each of these genes (Fig. 2A-E).

Several MEGs are associated with maternal DNA demethylation, and are thus likely regulated according to the mechanism proposed before (Köhler et al. 2012; Gehring 2013; Rodrigues and Zilberman 2015; Satyaki and Gehring 2017): DNA methylation in the regulatory regions of these genes has a repressive effect, which renders them inactive in sporophytic tissues, and as such, exclusively expressed in the endosperm (Fig. 2A). In these cases, the activity of DME is necessary to demethylate the maternal alleles, allowing for their expression in the endosperm. On the other hand, DNA methylation on the paternal allele is maintained from sporophytic tissues during pollen development (Hsieh et al. 2016), preventing the expression of this allele in the endosperm. In agreement with this, genes that are biallelically expressed in crosses with a met $1 \mathrm{fa}-$ ther are primarily expressed in the endosperm (Hsieh et al. 2011). For a subset of these MEGs, an additional repressive layer on the paternal allele can be enforced by FIS-PRC2 in the endosperm, through deposition of $\mathrm{H} 3 \mathrm{~K} 27 \mathrm{me} 3$ on the paternal alleles, as is the case of $M E A$ (Gehring et al. 2006; Jullien et al. 2006a). How this is achieved, and how DNA methylation influences H3K27me3 deposition at these loci, is still unknown.
Notwithstanding this model, and in light of the fact that several MEGs are not affected by dme, met1, or FIS-PRC2 mutants (Hsieh et al. 2011; Hornslien et al. 2019), we suggest an alternative mechanism of MEG regulation that does not depend on DME demethylation (Fig. 2B). If a gene is constitutively expressed, it will likely not be marked by DNA methylation in its flanking regions, since this has a negative effect on transcription (Niederhuth et al. 2016). Therefore, DME demethylation of the maternal allele is not required, and imprinted expression could be simply achieved through repression of the paternal allele. In this scenario, the mechanism to achieve parental DNA methylation asymmetries is distinct from that described in Figure 2A; notwithstanding, maternal hypomethylation is observed in both scenarios. Currently there are no defined candidates for what this paternal repressor could be; nevertheless, the accumulation of siRNAs and DNA methylation observed at some paternal alleles of MEGs in sperm points to RdDM as a potential candidate (Calarco et al. 2012). Paternal activity of RdDM was previously implicated in the repression of MEGs such as SDC and MOP9.5, among others (Vu et al. 2013; Hornslien et al. 2019). Interestingly, activity of RdDM seems to not be required in sperm, but rather in paternal sporophytic tissues (Vu et al. 2013), suggesting that the paternal imprint is established prior to gamete formation. It is also important to note that the imprinting of a considerable fraction of MEGs cannot be explained through the epigenetic marks assessed so far (DNA methylation and paternal H3K27me3) (Table 1). Therefore, additional unknown epigenetic mechanisms must be involved in the regulation of these genes. Further experimental work is required to identify what these mechanisms are and how they contribute to imprinted expression.

In the case of PEGs, we envision three distinct mechanisms (Fig. 2C-E), two of which could function exclusively with $\mathrm{H} 3 \mathrm{~K} 27 \mathrm{me} 3$ as the primary imprint (Fig. 2D,E). The classical model of PEG regulation depends on maternal demethylation through DME, which in turn facilitates H3K27me3 deposition (Fig. 2C; Köhler et al. 2012; Gehring 2013; Rodrigues and Zilberman 2015; Satyaki and Gehring 2017). For most PEGs, this is further associated with the deposition of H3K9me2 and CHG methylation, which possibly reinforces silencing of the maternal alleles (Moreno-Romero et al. 2019). The enzymes depositing H3K9me2 and CHG methylation on maternal alleles of PEG remain to be elucidated, as well as the relevance of this double modification for repression. Unlike the case of the MEGs represented in Figure 2A, DNA methylation in the flanking regions of these PEGs does not seem to have a repressive effect, since the paternal allele is expressed despite the presence of this mark. Consequently, these PEGs are potentially expressed in other tissues besides the endosperm. This points to DNA methylation functioning in these genes as a mechanism of exclusion of $\mathrm{H} 3 \mathrm{~K} 27 \mathrm{me} 3$, rather than having a direct repressive effect on transcription. In line with this, Zhang et al. (2014) observed that maize PEGs which are not exclusively expressed in the endosperm are often associated with 
maternal hypomethylated DMRs, and maternal accumulation of $\mathrm{H} 3 \mathrm{~K} 27 \mathrm{me} 3$.

In a different subset of PEGs, the presence of maternal $\mathrm{H} 3 \mathrm{~K} 27 \mathrm{me} 3$ is detected independently of the occurrence of DMRs (Table 1; Fig. 2D). Lack of DMRs in the flanking regions of these genes suggests that they are potentially expressed in other tissues besides the endosperm. Imprinted expression of these genes could thus be achieved through repression of maternal alleles in a DME-independent manner, possibly through the action of central cell-specific transcription factors that guide FIS-PRC2 to the target regions (Xiao et al. 2017). Since these maternal regions are not DNA methylated, deposition of H3K27me3 would not be counteracted (Fig. 2D).

Interestingly, in maize, it has been observed that PEGs that are expressed exclusively in the endosperm are often marked by H3K27me3 in other tissues (Makarevitch et al. 2013; Zhang et al. 2014). Thus, this points to a third scenario of PEG regulation, where the activation of these genes in the endosperm would only require removal of H3K27me3 from the paternal allele (Fig. 2E; Zhang et al. 2014). Since PRC2 activity is reduced in sperm (Fig. 1C; Luo et al. 2000; Spillane et al. 2000; Schoft et al. 2011), this could be easily achieved. In parallel, the maternal allele could remain repressed through maintenance of the H3K27me3 marks present in sporophytic tissues (Fig. 2E). While it has been shown that the levels of this histone mark are reduced prior to meiosis of the megaspore mother cell (MMC) in A. thaliana (She et al. 2013), it is currently unknown how this decrease of $\mathrm{H} 3 \mathrm{~K} 27 \mathrm{me} 3$ is achieved, and to which extent this affects genes that are marked in sporophytic tissues. Further understanding of H3K27me3 dynamics during female gametogenesis will be crucial to assess the validity of this scenario.

\section{Conclusions and perspectives}

Since the identification of the first imprinted gene in plants (Kermicle 1970), major progress has been made in uncovering the regulatory mechanisms conferring parental-specific gene expression in a wide range of plant species. These efforts have allowed the unveiling of the role of several key epigenetic players for imprinting establishment, such as DME and FIS-PRC2. Nevertheless, it is evident that the current epigenetic models cannot be generalized to explain the imprinting of all genes. The body of data generated during the latest years and discussed here suggests that the regulation of imprinting in plants is likely explained through a combination of several different epigenetic mechanisms. These mainly include DNA methylation and $\mathrm{H} 3 \mathrm{~K} 27 \mathrm{me} 3$, while some additional epigenetic modifications such as $\mathrm{H} 3 \mathrm{~K} 9 \mathrm{me} 2$ are emerging as important factors in the regulation of a subset of genes. Defining the role of these modifications, as well as the machineries establishing them are important tasks to be addressed in the future. While DNA methylation has been previously recognized to be solely responsible for the imprinting of some genes, a similar role for $\mathrm{H} 3 \mathrm{~K} 27 \mathrm{me} 3$ has yet to be experimentally assessed. Here, we suggest that
H3K27me3 can act both as a primary and secondary imprint, and that this is likely important for the regulation of many imprinted genes, especially PEGs, similarly to what has been previously shown in animals. Testing this model would be an important step forward in understanding imprinting regulation in plants. Recent advances in the isolation of endosperm and gamete cells (Park et al. 2016; Moreno-Romero et al. 2017; Santos et al. 2017; Zheng and Gehring 2019), as well as in techniques to assess the epigenome of these tissues (Moreno-Romero et al. 2017; Zheng and Gehring 2019) will hopefully contribute to deepen our understanding of the epigenetic pathways regulating imprinting in plants.

\section{Acknowledgments}

We thank Miyuki Nakamura for constructive comments to the figures. This work was supported by a grant from the Swedish Research Council (to C.K.) and support from the Göran Gustafsson Foundation for Research in Natural Sciences and Medicine (to C.K.).

\section{References}

Alabert C, Bukowski-Wills J-C, Lee S-B, Kustatscher G, Nakamura K, de Lima Alves F, Menard P, Mejlvang J, Rappsilber J, Groth A. 2014. Nascent chromatin capture proteomics determines chromatin dynamics during DNA replication and identifies unknown fork components. Nat Cell Biol 16: 281291. doi: $10.1038 /$ ncb2918

Barlow DP. 1993. Methylation and imprinting: from host defense to gene regulation? Science 260:309-310. doi:10.1126/science .8469984

Barlow DP. 1994. Imprinting: a gamete's point of view. Trends Genet 10: 194-199. doi:10.1016/0168-9525(94)90255-0

Barlow DP. 1995. Gametic imprinting in mammals. Science 270: 1610-1613. doi:10.1126/science.270.5242.1610

Barlow DP, Bartolomei MS. 2014. Genomic imprinting in mammals. Cold Spring Harb Perspect Biol 6: a018382. doi:10 $.1101 /$ cshperspect.a018382

Baroux C, Grossniklaus U. 2019. Seeds-an evolutionary innovation underlying reproductive success in flowering plants. Curr Top Dev Biol 131: 605-642. doi:10.1016/bs.ctdb.2018.11.017.

Batista RA, Moreno-Romero J, Qiu Y, van Boven J, Santos-González J, Figueiredo DD, Köhler C. 2019. The MADS-box transcription factor PHERES1 controls imprinting in the endosperm by binding to domesticated transposons. Elife. 8: 616698. doi:10.7554/eLife.50541

Belmonte MF, Kirkbride RC, Stone SL, Pelletier JM, Bui AQ, Yeung EC, Hashimoto M, Fei J, Harada CM, Munoz MD, et al. 2013. Comprehensive developmental profiles of gene activity in regions and subregions of the Arabidopsis seed. Proc Natl Acad Sci 110: E435-E444. doi:10.1073/pnas.1222061110

Bemer M, Heijmans K, Airoldi C, Davies B, Angenent GC. 2010. An atlas of type I MADS box gene expression during female gametophyte and seed development in Arabidopsis. Plant Physiol 154: 287-300. doi:10.1104/pp.110.160770

Blackledge NP, Rose NR, Klose RJ. 2015. Targeting Polycomb systems to regulate gene expression: modifications to a complex story. Nat Rev Mol Cell Biol 16: 643-649. doi:10.1038/ nrm4067 
Borges F, Gomes G, Gardner R, Moreno N, McCormick S, Feijó JA, Becker JD. 2008. Comparative transcriptomics of Arabidopsis sperm cells. Plant Physiol 148: 1168-1181. doi:10 $.1104 /$ pp.108.125229

Brink RA, Cooper DC. 1947. The endosperm in seed development. Bot Rev 13: 423-477. doi:10.1007/BF02861548

Calarco JP, Borges F, Donoghue MTA, Van Ex F, Jullien PE, Lopes T, Gardner R, Berger F, Feijó JA, Becker JD, et al. 2012. Reprogramming of DNA methylation in pollen guides epigenetic inheritance via small RNA. Cell 151: 194-205. doi:10.1016/i .cell.2012.09.001

Chen C, Li T, Zhu S, Liu Z, Shi Z, Zheng X, Chen R, Huang J, Shen Y, Luo S, et al. 2018. Characterization of imprinted genes in rice reveals conservation of regulation and imprinting with other plant species. Plant Physiol 177: 1754-1771. doi:10 $.1104 /$ pp. 17.01621

Choi Y, Gehring M, Johnson L, Hannon M, Harada JJ, Goldberg RB, Jacobsen SE, Fischer RL. 2002. DEMETER, a DNA glycosylase domain protein, is required for endosperm gene imprinting and seed viability in Arabidopsis. Cell 110: 33-42. doi:10.1016/S0092-8674(02)00807-3

Coleman RT, Struhl G. 2017. Causal role for inheritance of H3K27me3 in maintaining the off state of a Drosophila HOX gene. Science 356: eaai8236. doi:10.1126/science.aai8236

Costa LM, Yuan J, Rouster J, Paul W, Dickinson H, GutierrezMarcos JF. 2012. Maternal control of nutrient allocation in plant seeds by genomic imprinting. Curr Biol 22: 160-165. doi:10.1016/j.cub.2011.11.059

Cuerda-Gil D, Slotkin RK. 2016. Non-canonical RNA-directed DNA methylation. Nat Plants 2: 16163. doi:10.1038/nplants .2016 .163

Deleris A, Stroud H, Bernatavichute Y, Johnson E, Klein G, Schubert D, Jacobsen SE. 2012. Loss of the DNA methyltransferase MET1 induces H3K9 hypermethylation at PcG target genes and redistribution of $\mathrm{H} 3 \mathrm{~K} 27$ trimethylation to transposons in Arabidopsis thaliana. PLoS Genet 8: e1003062. doi:10 .1371/journal.pgen.1003062

Del Toro-De León G, Köhler C. 2019. Endosperm-specific transcriptome analysis by applying the INTACT system. Plant Reprod 32: 55-61. doi: 10.1007/s00497-018-00356-3.

Del Toro-De León G, García-Aguilar M, Gillmor CS. 2014. Nonequivalent contributions of maternal and paternal genomes to early plant embryogenesis. Nature 514: 624-627. doi:10.1038/ nature 13620

Drews GN, Koltunow AMG. 2011. The female gametophyte. Arab B 9: e0155. doi:10.1199/tab.0155

Erdmann RM, Satyaki PR V, Klosinska M, Gehring M. 2017. A small RNA pathway mediates allelic dosage in endosperm. Cell Rep 21: 3364-3372. doi:10.1016/j.celrep.2017.11.078

Erilova A, Brownfield L, Exner V, Rosa M, Twell D, Scheid OM, Hennig L, Köhler C. 2009. Imprinting of the polycomb group gene MEDEA serves as a ploidy sensor in Arabidopsis. PLoS Genet 5: e1000663. doi:10.1371/journal.pgen.1000663

Field LM, Lyko F, Mandrioli M, Prantera G. 2004. DNA methylation in insects. Insect Mol Biol 13: 109-115. doi:10.1111/j .0962-1075.2004.00470.x

Figueiredo DD, Batista RA, Roszak PJ, Köhler C. 2015. Auxin production couples endosperm development to fertilization. Nat Plants 1: 15184. doi:10.1038/nplants.2015.184

Florez-Rueda AM, Paris M, Schmidt A, Widmer A, Grossniklaus U, Städler T. 2016. Genomic imprinting in the endosperm is systematically perturbed in abortive hybrid tomato seeds. Mol Biol Evol 33: 2935-2946. doi:10.1093/molbev/msw175
Gehring M. 2013. Genomic imprinting: insights from plants. Annu Rev Genet 47: 187-208. doi:10.1146/annurev-genet110711-155527

Gehring M, Huh JH, Hsieh T-F, Penterman J, Choi Y, Harada JJ, Goldberg RB, Fischer RL. 2006. DEMETER DNA glycosylase establishes MEDEA polycomb gene self-imprinting by allelespecific demethylation. Cell 124: 495-506. doi:10.1016/j.cell .2005.12.034

Gehring M, Bubb KL, Henikoff S. 2009. Extensive demethylation of repetitive elements during seed development underlies gene imprinting. Science 324: 1447-1451. doi:10.1126/sci ence. 1171609

Gehring M, Missirian V, Henikoff S. 2011. Genomic analysis of parent-of-origin allelic expression in Arabidopsis thaliana Seeds. PLoS One 6: e23687. doi:10.1371/journal.pone .0023687

Gerald JNF, Hui PS, Berger F. 2009. Polycomb group-dependent imprinting of the actin regulator AtFH5 regulates morphogenesis in Arabidopsis thaliana. Development 136: 3399-3404. doi: $10.1242 /$ dev.036921

Gong Z, Morales-Ruiz T, Ariza RR, Roldán-Arjona T, David L, Zhu J-K. 2002. ROS1, a repressor of transcriptional gene silencing in Arabidopsis, encodes a DNA glycosylase/lyase. Cell 111: 803-814. doi:10.1016/S0092-8674(02)01133-9

Grossniklaus U, Vielle-Calzada JP, Hoeppner MA, Gagliano WB. 1998. Maternal control of embryogenesis by MEDEA, a polycomb group gene in Arabidopsis. Science 280: 446-450. doi:10.1126/science.280.5362.446

Gutierrez-Marcos JF, Pennington PD, Costa LM, Dickinson HG. 2003. Imprinting in the endosperm: a possible role in preventing wide hybridization. Philos Trans $R$ Soc Lond B Biol Sci 358:1105-1111. doi:10.1098/rstb.2003.1292

Gutiérrez-Marcos JF, Costa LM, Biderre-Petit C, Khbaya B, O'Sullivan DM, Wormald M, Perez P, Dickinson HG. 2004. Maternally expressed genel is a novel maize endosperm transfer cell-specific gene with a maternal parent-of-origin pattern of expression. Plant Cell 16: 1288-1301. doi:10.1105/tpc.019778

Haig D, Westoby M. 1989. Parent-specific gene expression and the triploid endosperm. Am Nat 134: 147-155. doi:10.1086/ 284971

Hansen KH, Bracken AP, Pasini D, Dietrich N, Gehani SS, Mon$\operatorname{rad}$ A, Rappsilber J, Lerdrup M, Helin K. 2008. A model for transmission of the H3K27me3 epigenetic mark. Nat Cell Biol 10: 1291-1300. doi:10.1038/ncb1787

Hatorangan MR, Laenen B, Steige KA, Slotte T, Köhler C. 2016. Rapid evolution of genomic imprinting in two species of the Brassicaceae. Plant Cell 28: 1815-1827. doi:10.1105/tpc.16 .00304

Hornslien KS, Miller JR, Grini PE. 2019. Regulation of parent-oforigin allelic expression in the endosperm. Plant Physiol 180: 1498-1519. doi:10.1104/pp.19.00320

Hsieh TF, Ibarra CA, Silva P, Zemach A, Eshed-Williams L, Fischer RL, Zilberman D. 2009. Genome-wide demethylation of Arabidopsis endosperm. Science 324: 1451-1454. doi:10 $.1126 /$ science. 1172417

Hsieh TF, Shin J, Uzawa R, Silva P, Cohen S, Bauer MJ, Hashimoto M, Kirkbride RC, Harada JJ, Zilberman D, et al. 2011. Regulation of imprinted gene expression in Arabidopsis endosperm. PNAS 108: 1755-1762. doi:10.1073/pnas.1019273108

Hsieh P-H, He S, Buttress T, Gao H, Couchman M, Fischer RL, Zilberman D, Feng X. 2016. Arabidopsis male sexual lineage exhibits more robust maintenance of CG methylation than somatic tissues. Proc Natl Acad Sci 113: 15132-15137. doi:10.1073/pnas.1619074114 
Huang F, Zhu Q, Zhu A, Wu X, Xie L, Wu X, Helliwell C, Chaudhury A, Finnegan EJ, Luo M. 2017. Mutants in the imprinted PICKLE RELATED 2 gene suppress seed abortion of fertilization independent seed class mutants and paternal excess interploidy crosses in Arabidopsis. Plant I 90: 383-395. doi:10.1111/tpj. 13500

Ibarra CA, Feng X, Schoft VK, Hsieh T-F, Uzawa R, Rodrigues JA, Zemach A, Chumak N, Machlicova A, Nishimura T, et al. 2012. Active DNA demethylation in plant companion cells reinforces transposon methylation in gametes. Science 337: 1360-1364. doi:10.1126/science.1224839

Inoue A, Jiang L, Lu F, Suzuki T, Zhang Y. 2017a. Maternal H3K27me3 controls DNA methylation-independent imprinting. Nature 547: 419-424. doi:10.1038/nature23262

Inoue A, Jiang L, Lu F, Zhang Y. 2017b. Genomic imprinting of Xist by maternal H3K27me3. Genes Dev 31: 1927-1932. doi:10.1101/gad.304113.117

Inoue A, Chen Z, Yin Q, Zhang Y. 2018. Maternal Eed knockout causes loss of $\mathrm{H} 3 \mathrm{~K} 27 \mathrm{me} 3$ imprinting and random $\mathrm{X}$ inactivation in the extraembryonic cells. Genes Dev 32: 1525-1536. doi:10.1101/gad.318675.118

Jahnke S, Scholten S. 2009. Epigenetic resetting of a gene imprinted in plant embryos. Curr Biol 19: 1677-1681. doi:10.1016/j .cub.2009.08.053

Jiang D, Berger F. 2017. DNA replication-coupled histone modification maintains Polycomb gene silencing in plants. Science 357: 1146-1149. doi:10.1126/science.aan4965

Jiang H, Kohler C. 2012. Evolution, function, and regulation of genomic imprinting in plant seed development. I Exp Bot 63: 4713-4722. doi:10.1093/jxb/ers145

Jiang H, Moreno-Romero J, Santos-González J, De Jaeger G, Gevaert K, Van De Slijke E, Köhler C. 2017. Ectopic application of the repressive histone modification $\mathrm{H} 3 \mathrm{~K} 9 \mathrm{me} 2$ establishes post-zygotic reproductive isolation in Arabidopsis thaliana. Genes Dev 31: 1272-1287. doi:10.1101/gad.299347 .117

Jullien PE, Katz A, Oliva M, Ohad N, Berger F. 2006a. Polycomb group complexes self-regulate imprinting of the Polycomb group gene MEDEA in Arabidopsis. Curr Biol 16: 486-492. doi:10.1016/j.cub.2006.01.020

Jullien PE, Kinoshita T, Ohad N, Berger F. 2006b. Maintenance of DNA methylation during the Arabidopsis life cycle is essential for parental imprinting. Plant Cell Online 18: 13601372. doi:10.1105/tpc. 106.041178

Jullien PE, Susaki D, Yelagandula R, Higashiyama T, Berger F. 2012. DNA Methylation dynamics during sexual reproduction in Arabidopsis thaliana. Curr Biol 22: 1825-1830. doi:10.1016/j.cub.2012.07.061

Kermicle JL. 1970. Dependence of the R-mottled aleurone phenotype in maize on mode of sexual transmission. Genetics 66: 69-85.

Kim MY, Ono A, Scholten S, Kinoshita T, Zilberman D, Okamoto T, Fischer RL. 2019. DNA demethylation by ROS1a in rice vegetative cells promotes methylation in sperm. Proc Natl Acad Sci 116: 9652-9657. doi:10.1073/pnas.1821435116

Kinoshita T, Yadegari R, Harada JJ, Goldberg RB, Fischer RL. 1999. Imprinting of the MEDEA polycomb gene in the Arabidopsis endosperm. Plant Cell 11: 1945-1952. doi:10.1105/tpc .11 .10 .1945

Kinoshita T, Miura A, Choi Y, Kinoshita Y, Cao X, Jacobsen SE, Fischer RL, Kakutani T. 2004. One-way control of FWA imprinting in Arabidopsis endosperm by DNA methylation. Science (80-) 303: 521-523. doi:10.1126/science.1089835

Kinoshita Y, Saze H, Kinoshita T, Miura A, Soppe WIJ, Koornneef M, Kakutani T. 2006. Control of FWA gene silencing in Arabi- dopsis thaliana by SINE-related direct repeats. Plant J 49: 3845. doi:10.1111/j.1365-313X.2006.02936.x

Klosinska M, Picard CL, Gehring M. 2016. Conserved imprinting associated with unique epigenetic signatures in the Arabidopsis genus. Nat Plants 2: 16145. doi:10.1038/nplants.2016.145

Köhler C, Wolff P, Spillane C. 2012. Epigenetic mechanisms underlying genomic imprinting in plants. Annu Rev Plant Biol 63: 331-352. doi:10.1146/annurev-arplant-042811-105514

Kradolfer D, Wolff P, Jiang H, Siretskiy A, Köhler C. 2013. An imprinted gene underlies postzygotic reproductive isolation in Arabidopsis thatiana. Dev Cell 26: 525-535. doi:10.1016/j .devcel.2013.08.006

Laprell F, Finkl K, Müller J. 2017. Propagation of Polycomb-repressed chromatin requires sequence-specific recruitment to DNA. Science 356: 85-88. doi:10.1126/science.aai8266

Law JA, Jacobsen SE. 2010. Establishing, maintaining and modifying DNA methylation patterns in plants and animals. Nat ReV Genet 11: 204-220. doi:10.1038/nrg2719

Lin BY. 1984. Ploidy barrier to endosperm development in maize. Genetics 107: 103-115.

Luo M, Bilodeau P, Dennis ES, Peacock WJ, Chaudhury A. 2000. Expression and parent-of-origin effects for FIS2, MEA, and FIE in the endosperm and embryo of developing Arabidopsis seeds. Proc Natl Acad Sci 97: 10637-10642. doi:10.1073/ pnas. 170292997

Makarevich G, Villar CBR, Erilova A, Kohler C. 2008. Mechanism of PHERES1 imprinting in Arabidopsis. J Cell Sci 121: 906-912. doi:10.1242/jcs.023077

Makarevitch I, Eichten SR, Briskine R, Waters AJ, Danilevskaya ON, Meeley RB, Myers CL, Vaughn MW, Springer NM. 2013. Genomic distribution of maize facultative heterochromatin marked by trimethylation of H3K27. Plant Cell 25: 780-793. doi:10.1105/tpc.112.106427

Margueron R, Justin N, Ohno K, Sharpe ML, Son J, Drury WJ III, Voigt P, Martin SR, Taylor WR, De Marco V, et al. 2009. Role of the polycomb protein EED in the propagation of repressive histone marks. Nature 461: 762-767. doi:10 $.1038 /$ nature08398

Martínez G, Panda K, Köhler C, Slotkin RK. 2016. Silencing in sperm cells is directed by RNA movement from the surrounding nurse cell. Nat Plants 2: 16030. doi:10.1038/ nplants. 2016.30

Martinez G, Wolff P, Wang Z, Moreno-Romero J, Santos-González J, Conze LL, DeFraia C, Slotkin RK, Köhler C. 2018. Paternal easiRNAs regulate parental genome dosage in Arabidopsis. Nat Genet 50: 193-198. doi:10.1038/s41588017-0033-4

McDonald JF, Matzke MA, Matzke AJ. 2005. Host defenses to transposable elements and the evolution of genomic imprinting. Cytogenet Genome Res 110: 242-249. doi:10.1159/ 000084958

Morales-Ruiz T, Ortega-Galisteo AP, Ponferrada-Marín MI, Martínez-Macías MI, Ariza RR, Roldán-Arjona T. 2006. DEMETER and REPRESSOR OF SILENCING 1 encode 5methylcytosine DNA glycosylases. Proc Natl Acad Sci 103: 6853-6858. doi:10.1073/pnas.0601109103

Moreno-Romero J, Jiang H, Santos-González J, Köhler C. 2016. Parental epigenetic asymmetry of PRC2-mediated histone modifications in the Arabidopsis endosperm. EMBO J 35: 1298-1311. doi:10.15252/embj.201593534

Moreno-Romero J, Santos-González J, Hennig L, Köhler C. 2017. Applying the INTACT method to purify endosperm nuclei and to generate parental-specific epigenome profiles. Nat Protoc 12: 238-254. doi:10.1038/nprot.2016.167 
Moreno-Romero J, Del Toro-De León G, Yadav VK, SantosGonzález J, Köhler C. 2019. Epigenetic signatures associated with imprinted paternally expressed genes in the Arabidopsis endosperm. Genome Biol 20: 41. doi:10.1186/s13059-0191652-0

Mozgova I, Hennig L. 2015. The polycomb group protein regulatory network. Annu Rev Plant Biol 66: 269-296. doi:10 .1146/annurev-arplant-043014-115627

Mozgova I, Köhler C, Hennig L. 2015. Keeping the gate closed: functions of the polycomb repressive complex PRC2 in development. Plant J 83: 121-132. doi:10.1111/tpj.12828

Niederhuth CE, Bewick AJ, Ji L, Alabady MS, Do KK, Li Q, Rohr NA, Rambani A, Burke JM, Udall JA, et al. 2016. Widespread natural variation of DNA methylation within angiosperms. Genome Biol 17: 194. doi:10.1186/s13059-016-1059-0

Nodine MD, Bartel DP. 2012. Maternal and paternal genomes contribute equally to the transcriptome of early plant embryos. Nature 482: 94-97. doi:10.1038/nature10756

Ortega-Galisteo AP, Morales-Ruiz T, Ariza RR, Roldán-Arjona T. 2008. Arabidopsis DEMETER-LIKE proteins DML2 and DML3 are required for appropriate distribution of DNA methylation marks. Plant Mol Biol 67: 671-681. doi:10.1007/ s11103-008-9346-0

Park K, Kim MY, Vickers M, Park J-S, Hyun Y, Okamoto T, Zilberman D, Fischer RL, Feng X, Choi Y, et al. 2016. DNA demethylation is initiated in the central cells of Arabidopsis and rice. Proc Natl Acad Sci 113: 15138-15143. doi:10.1073/pnas .1619047114

Patten MM, Ross L, Curley JP, Queller DC, Bonduriansky R, Wolf JB. 2014. The evolution of genomic imprinting: theories, predictions and empirical tests. Heredity 113: 119-128. doi:10 $.1038 /$ hdy.2014.29

Penterman J, Zilberman D, Huh JH, Ballinger T, Henikoff S, Fischer RL. 2007. DNA demethylation in the Arabidopsis genome. Proc Natl Acad Sci 104: 6752-6757. doi:10.1073/pnas .0701861104

Pignatta D, Erdmann RM, Scheer E, Picard CL, Bell GW, Gehring M. 2014. Natural epigenetic polymorphisms lead to intraspecific variation in Arabidopsis gene imprinting. Elife 3: e03198. doi:10.7554/eLife.03198

Pires ND, Grossniklaus U. 2014. Different yet similar: evolution of imprinting in flowering plants and mammals. F1000Prime Rep 6: 63. doi:10.12703/P6-63

Raissig MT, Bemer M, Baroux C, Grossniklaus U. 2013. Genomic imprinting in the Arabidopsis embryo is partly regulated by PRC2. PLoS Genet 9: e1003862. doi:10.1371/journal.pgen .1003862

Rebernig CA, Lafon-Placette C, Hatorangan MR, Slotte T, Köhler C. 2015. Non-reciprocal interspecies hybridization barriers in the Capsella genus are established in the endosperm. PLoS Genet 11: e1005295. doi:10.1371/journal.pgen.1005295

Rodrigues JA, Zilberman D. 2015. Evolution and function of genomic imprinting in plants. Genes Dev 29: 2517-2531.

Rodrigues JA, Ruan R, Nishimura T, Sharma MK, Sharma R, Ronald PC, Fischer RL, Zilberman D. 2013. Imprinted expression of genes and small RNA is associated with localized hypomethylation of the maternal genome in rice endosperm. Proc Natl Acad Sci 110: 7934-7939. doi:10.1073/pnas .1306164110

Roth M, Florez-Rueda AM, Städler T. 2019. Differences in effective ploidy drive genome-wide endosperm expression polarization and seed failure in wild tomato hybrids. Genetics 212: 141-152. doi:10.1534/genetics.119.302056

Roudier F, Ahmed I, Bérard C, Sarazin A, Mary-Huard T, Cortijo S, Bouyer D, Caillieux E, Duvernois-Berthet E, Al-Shikhley L, et al. 2011. Integrative epigenomic mapping defines four main chromatin states in Arabidopsis. EMBO J 30: 1928-1938. doi:10.1038/emboj.2011.103

Santos MR, Bispo C, Becker JD. 2017. Isolation of Arabidopsis pollen, sperm cells, and vegetative nuclei by fluorescence-activated cell sorting (FACS). Methods Mol Biol 1669:. pp. 193210. doi:10.1007/978-1-4939-7286-9_16

Satyaki PRV, Gehring M. 2017. DNA methylation and imprinting in plants: machinery and mechanisms. Crit Rev Biochem Mol Biol 52: 163-175. doi:10.1080/10409238.2017.1279119

Saze H, Scheid OM, Paszkowski J. 2003. Maintenance of CpG methylation is essential for epigenetic inheritance during plant gametogenesis. Nat Genet 34: 65-69. doi:10.1038/ ng1138

Schatlowski N, Wolff P, Santos-González J, Schoft V, Siretskiy A, Scott R, Tamaru H, Köhler C. 2014. Hypomethylated pollen bypasses the interploidy hybridization barrier in Arabidopsis. Plant Cell 26: 3556-3568. doi:10.1105/tpc.114.130120

Schoft VK, Chumak N, Choi Y, Hannon M, Garcia-Aguilar M, Machlicova A, Slusarz L, Mosiolek M, Park J-S, Park GT, et al. 2011. Function of the DEMETER DNA glycosylase in the Arabidopsis thaliana male gametophyte. Proc Natl Acad Sci 108: 8042-8047. doi:10.1073/pnas.1105117108

Scott RJ, Spielman M, Bailey J, Dickinson HG. 1998. Parent-of-origin effects on seed development in Arabidopsis thaliana. Development 125: 3329-3341.

Sekine D, Ohnishi T, Furuumi H, Ono A, Yamada T, Kurata N, Kinoshita T. 2013. Dissection of two major components of the post-zygotic hybridization barrier in rice endosperm. Plant J 76: 792-799. doi:10.1111/tpj.12333

She W, Grimanelli D, Rutowicz K, Whitehead MWJ, Puzio M, Kotlinski M, Jerzmanowski A, Baroux C. 2013. Chromatin reprogramming during the somatic-to-reproductive cell fate transition in plants. Development 140: 4008-4019. doi:10 $.1242 /$ dev.095034

Slotkin RK, Vaughn M, Borges F, Tanurdžić M, Becker JD, Feijó JA, Martienssen RA. 2009. Epigenetic reprogramming and small RNA silencing of transposable elements in Pollen. Cell 136: 461-472. doi:10.1016/j.cell.2008.12.038

Spillane C, MacDougall C, Stock C, Köhler C, Vielle-Calzada JP, Nunes SM, Grossniklaus U, Goodrich J. 2000. Interaction of the Arabidopsis polycomb group proteins FIE and MEA mediates their common phenotypes. Curr Biol 10: 1535-1538. doi:10.1016/S0960-9822(00)00839-3

Stoute AI, Varenko V, King GJ, Scott RJ, Kurup S. 2012. Parental genome imbalance in Brassica oleracea causes asymmetric triploid block. Plant J 71: 503-516.

Tiwari S, Schulz R, Ikeda Y, Dytham L, Bravo J, Mathers L, Spielman M, Guzman P, Oakey RJ, Kinoshita T, et al. 2008. MATERNALLY EXPRESSED PAB C-TERMINAL, a novel imprinted gene in Arabidopsis, encodes the conserved C-terminal domain of polyadenylate binding proteins. PLANT CELL ONLINE 20: 2387-2398. doi:10.1105/tpc.108.061929

Tiwari S, Spielman M, Schulz R, Oakey RJ, Kelsey G, Salazar A, Zhang K, Pennell R, Scott RJ. 2010. Transcriptional profiles underlying parent-of-origin effects in seeds of Arabidopsis thaliana. BMC Plant Biol 10: 72. doi:10.1186/1471-2229-1072

Vu TM, Nakamura M, Calarco JP, Susaki D, Lim PQ, Kinoshita T, Higashiyama T, Martienssen RA, Berger F. 2013. RNA-directed DNA methylation regulates parental genomic imprinting at several loci in Arabidopsis. Development 140: 2953-2960. doi:10.1242/dev.092981

Wang D, Tyson MD, Jackson SS, Yadegari R. 2006. Partially redundant functions of two SET-domain polycomb-group 
proteins in controlling initiation of seed development in Arabidopsis. Proc Natl Acad Sci 103: 13244-13249. doi:10.1073/ pnas.0605551103

Wang G, Jiang H, Del Toro de León G, Martinez G, Köhler C. 2018. Sequestration of a transposon-derived siRNA by a target mimic imprinted gene induces postzygotic reproductive isolation in Arabidopsis. Dev Cell 46: 696-705.e4. doi:10.1016/j .devcel.2018.07.014

Waters AJ, Bilinski P, Eichten SR, Vaughn MW, Ross-Ibarra J, Gehring M, Springer NM. 2013. Comprehensive analysis of imprinted genes in maize reveals allelic variation for imprinting and limited conservation with other species. Proc Natl Acad Sci 110: 19639-19644. doi:10.1073/pnas.1309182110

Weinhofer I, Hehenberger E, Roszak P, Hennig L, Köhler C. 2010. H3K27me3 profiling of the endosperm implies exclusion of polycomb group protein targeting by DNA methylation. PLOS Genet 6: e100115. doi:10.1371/journal.pgen.1001152

Wolff P, Weinhofer I, Seguin J, Roszak P, Beisel C, Donoghue MTAA, Spillane C, Nordborg M, Rehmsmeier M, Köhler C. 2011. High-Resolution analysis of parent-of-origin allelic expression in the Arabidopsis endosperm. PLoS Genet 7: e1002126. doi:10.1371/journal.pgen.1002126

Wolff P, Jiang H, Wang G, Santos-González J, Köhler C. 2015. Paternally expressed imprinted genes establish postzygotic hybridization barriers in Arabidopsis thaliana. Elife 4: e10074. doi:10.7554/eLife.10074

Wuest SE, Vijverberg K, Schmidt A, Weiss M, Gheyselinck J, Lohr M, Wellmer F, Rahnenführer J, von Mering C, Grossniklaus U. 2010. Arabidopsis female gametophyte gene expression map reveals similarities between plant and animal gametes. Curr Biol 20: 506-512. doi:10.1016/j.cub.2010.01.051

Xiao J, Jin R, Yu X, Shen M, Wagner JD, Pai A, Song C, Zhuang M, Klasfeld S, He C, et al. 2017. Cis and trans determinants of epigenetic silencing by Polycomb repressive complex 2 in Arabidopsis. Nat Genet 49: 1546-1552. doi:10.1038/ng.3937
Xu W, Dai M, Li F, Liu A. 2014. Genomic imprinting, methylation and parent-of-origin effects in reciprocal hybrid endosperm of castor bean. Nucleic Acids Res 42: 6987-6998. doi:10.1093/nar/gku375

Yuan J, Chen S, Jiao W, Wang L, Wang L, Ye W, Lu J, Hong D, You S, Cheng Z, et al. 2017. Both maternally and paternally imprinted genes regulate seed development in rice. New Phytol 216: 373-387. doi:10.1111/nph.14510

Zemach A, Kim MY, Silva P, Rodrigues JA, Dotson B, Brooks MD, Zilberman D. 2010. Local DNA hypomethylation activates genes in rice endosperm. Proc Natl Acad Sci 107: 1872918734. doi:10.1073/pnas.1009695107

Zhang M, Zhao H, Xie S, Chen J, Xu Y, Wang K, Zhao H, Guan H, $\mathrm{Hu} \mathrm{X}$, Jiao Y, et al. 2011. Extensive, clustered parental imprinting of protein-coding and noncoding RNAs in developing maize endosperm. Proc Natl Acad Sci 108: 20042-20047. doi:10.1073/pnas.1112186108

Zhang M, Xie S, Dong X, Zhao X, Zeng B, Chen J, Li H, Yang W, Zhao H, Wang G, et al. 2014. Genome-wide high resolution parental-specific DNA and histone methylation maps uncover patterns of imprinting regulation in maize. Genome Res $\mathbf{2 4}$ : 167-176. doi:10.1101/gr.155879.113

Zhang M, Li N, He W, Zhang H, Yang W, Liu B. 2016. Genomewide screen of genes imprinted in sorghum endosperm, and the roles of allelic differential cytosine methylation. Plant $J$ 85: 424-436. doi:10.1111/tpj.13116

Zhang H, Lang Z, Zhu J-K. 2018. Dynamics and function of DNA methylation in plants. Nat Rev Mol Cell Biol 19: 489-506. doi:10.1038/s41580-018-0016-z

Zheng X, Gehring M. 2019. Low-input chromatin profiling in Arabidopsis endosperm using CUT\&RUN. Plant Reprod 32: 6375. doi:10.1007/s00497-018-00358-1

Zhou Y, Wang Y, Krause K, Yang T, Dongus JA, Zhang Y, Turck F. 2018. Telobox motifs recruit CLF/SWN-PRC2 for H3K27me3 deposition via TRB factors in Arabidopsis. Nat Genet 50: 638644. doi:10.1038/s41588-018-0109-9 


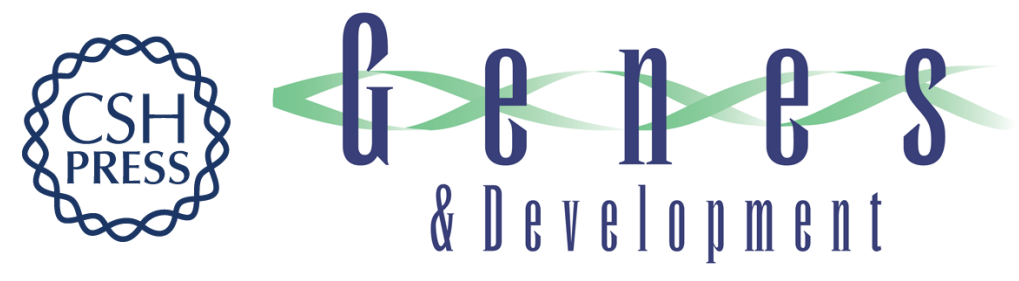

\section{Genomic imprinting in plants--revisiting existing models}

Rita A. Batista and Claudia Köhler

Genes Dev. 2020, 34:

Access the most recent version at doi:10.1101/gad.332924.119

Supplemental Material

References

Creative Commons License

Email Alerting Service
http://genesdev.cshlp.org/content/suppl/2019/12/20/34.1-2.24.DC1

This article cites 124 articles, 49 of which can be accessed free at: http://genesdev.cshlp.org/content/34/1-2/24.full.html\#ref-list-1

This article is distributed exclusively by Cold Spring Harbor Laboratory Press for the first six months after the full-issue publication date (see

http://genesdev.cshlp.org/site/misc/terms.xhtml). After six months, it is available under a Creative Commons License (Attribution-NonCommercial 4.0 International), as described at http://creativecommons.org/licenses/by-nc/4.0/.

Receive free email alerts when new articles cite this article - sign up in the box at the top right corner of the article or click here.

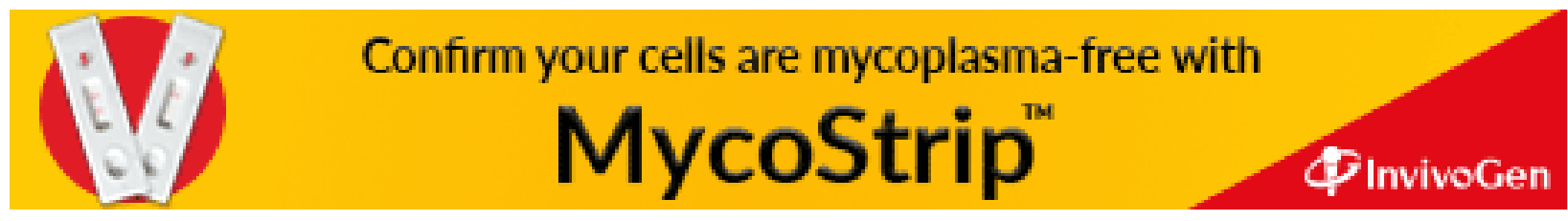

